\title{
Spatial Modeling of Biological Soil Crusts to Support Rangeland Assessment and Monitoring
}

\author{
Matthew A. Bowker, Jayne Belnap, ${ }^{2}$ and Mark E. Miller ${ }^{3}$ \\ Authors are ${ }^{1}$ Research Assistant, Department of Biological Sciences, Northern Arizona University, Box 5640, Flagstaff, \\ AZ 86011; ${ }^{2}$ Station Leader, and ${ }^{3}$ Research Scientist, US Geological Survey, 2290 SW Resource Blvd, Moab, UT 84532.
}

\begin{abstract}
Biological soil crusts are a diverse soil surface community, prevalent in semiarid regions, which function as ecosystem engineers and perform numerous important ecosystem services. Loss of crusts has been implicated as a factor leading to accelerated soil erosion and other forms of land degradation. To support assessment and monitoring efforts aimed at ensuring the sustainability of rangeland ecosystems, managers require spatially explicit information concerning potential cover and composition of biological soil crusts. We sampled low disturbance sites in Grand Staircase-Escalante National Monument (Utah, USA) to determine the feasibility of modeling the potential cover and composition of biological soil crusts in a large area. We used classification and regression trees to model cover of four crust types (light cyanobacterial, dark cyanobacterial, moss, lichen) and 1 cyanobacterial biomass proxy (chlorophyll $a$ ), based upon a parsimonious set of GIS (Geographic Information Systems) data layers (soil types, precipitation, and elevation). Soil type was consistently the best predictor, although elevation and precipitation were both invoked in the various models. Predicted and observed values for the dark cyanobacterial, moss, and lichen models corresponded moderately well $\left(R^{2}=0.49,0.64,0.55\right.$, respectively). Cover of late successional crust elements (moss + lichen + dark cyanobacterial) was also successfully modeled $\left(R^{2}=0.64\right)$. We were less successful with models of light cyanobacterial cover $\left(R^{2}=0.22\right)$ and chlorophyll a $\left(R^{2}=0.09\right)$. We believe that our difficulty modeling chlorophyll $a$ concentration is related to a severe drought and subsequent cyanobacterial mortality during the course of the study. These models provide the necessary reference conditions to facilitate the comparison between the actual cover and composition of biological soil crusts at a given site and their potential cover and composition condition so that sites in poor condition can be identified and management actions can be taken.
\end{abstract}

\section{Resumen}

Las costras biológicas de suelo son una comunidad diversa de la superficie del suelo, prevalecientes en las regiones semiáridas, y las cuales funcionan como ecosistemas y realizan numerosos servicios ecológico importantes. La perdida de estas costras has sido implicada como un factor que conduce a una erosión acelerada de suelo y otras formas de degradación de las tierras. Para sostener las acciones de evaluación y monitoreo encaminadas a asegurar la sostenibilidad de los ecosistemas de pastizal, los manejadores requieren de información espacial explícita concerniente a la cobertura potencial y composición de las costras biológicas del suelo. En el Monumento Nacional Grand Staircase-Escalante (Utah, USA) muestreamos sitios con poco disturbio para determinar la factibilidad de modelar la cobertura potencial y composición de la costra biológica de una área mayor. Utilizamos árboles de clasificación y regresión para modelar la cobertura de cuatro tipos de costra (cianobacterial clara, cianobacterial obscura, musgo, y liquen) y una derivación de la biomasa cianobacterial (chlorophyll a), basados en un parsimonioso juego de capas de datos de Sistemas de Información Geográfica (GIS) (tipos de suelos, precipitación, y elevación). El tipo de suelo fue consistentemente el mejor predictor, aunque la elevación y precipitación fueron invocadas en varios de los modelos. Los valores predichos y observados para las cianobacterias obscuras y musgos correspondieron moderadamente bien $\left(R^{2}=0.49,0.64,0.55\right.$, respectivamente). La cobertura de elementos de la costra de etapas serales finales (musgo + liquen + cianobacterias obscuras) fue también modelada exitosamente $\left(R^{2}=0.64\right)$. Fuimos menos exitosos con los modelos de la cobertura de cianobacterias claras $\left(R^{2}=0.22\right)$ y clorofila $a\left(R^{2}=0.09\right)$. Creemos que nuestra dificultad para modelar la concentración de clorofila $a$ esta relacionada a una severa sequía y la mortalidad subsecuente de las cianobacterias durante el curso de este estudio. Estos modelos proveen las condiciones de referencia necesarias para facilitar la comparación entre la cobertura y composición actuales de las costras biológicas del suelo en un sitio dado y su condición potencial de cobertura y composición de tal forma que sitios en condición pobre pueden ser identificados y pueden ser tomadas acciones de manejo.

Key Words: degradation thresholds, drylands, cryptobiotic soil crusts, lichens, mosses, rangeland health

Research was funded by Grand Staircase-Escalante National Monument, Bureau of Land Management. M.B. received additional support from the Merriam-Powell Center for Ecological Research, Northern Arizona University.

Correspondence: Matthew A. Bowker, Dept of Biological Sciences, Northern Arizona University, Box 5640, Flagstaff, AZ 86011. Email: Matthew.Bowker@nau.edu

Manuscript received 23 October 2005; manuscript accepted 7 May 2006.

\section{INTRODUCTION}

Loss of biological soil crusts (a soil surface community of mosses, lichens, cyanobacteria, and other organisms) in dryland range ecosystems, is both a component of and accelerator of land degradation (Belnap 1995). This is often expressed as soil erosion and lowered potential for productivity (Neff et al. 
2005). Thus, the retention of biological soil crusts can be an important means to prevent the crossing of degradation thresholds. Therefore, to support assessment and monitoring efforts aimed at ensuring the sustainability of dryland range ecosystems (Tongway and Hindley 1995; Pellant et al. 2000; Pyke et al. 2002; Rosentreter and Eldridge 2002; Herrick et al. 2005), managers require spatially explicit information concerning potential cover and composition of these communities.

Biological soil crusts can be considered ecosystem engineers in aridlands (organisms that control resource availability via alteration of physical state factors; Jones et al. 1997) because they: 1 ) aggregate surface soil and reduce erosion (Mazor et al. 1996), and 2) regulate the water runoff-infiltration balance (Warren 2001) and increase soil moisture retention (Alexander and Calvo 1990). Nutrient cycles and vascular plant performance are strongly influenced by biological soil crusts. Crust organisms enhance the nutrient status of soils via nitrogen $(\mathrm{N})$ fixation (Evans and Ehleringer 1993), carbon (C) fixation (Beymer and Klopatek 1991), entrapment of eolian silts and clays (Danin and Gaynor 1991; Reynolds et al. 2001), and chelation of metals (Belnap et al. 2003). Disturbance due to livestock grazing is the most widespread stressor of crust communities throughout their range. Depending on intensity, livestock disturbance of soil crusts generally results in a reduction of lichen and moss components, leaving depauperate cyanobacterial crusts and diminishing crust-provided ecosystem functions and services (Harper and Marble 1988; Belnap 1995, 1996). Estimates of recovery time from such disturbances are usually measured in decades (reviewed in Belnap and Eldridge 2003).

Traditionally, suitability for and timing and intensity of stocking has been largely informed by availability of livestock forage, primarily a socioeconomic consideration (Pendleton 1989). Although control of soil erosion and other forms of ecological degradation (e.g., loss of soil moisture and fertility, changes in vegetation structure) have long been concerns in rangeland management (Ellison 1949), range assessment protocols have been slow to adopt collection of more ecologically oriented data. In the context of arid lands range management, knowledge of the potential condition of crust communities is useful because it provides a means to assess the degree of disturbance to this important ecosystem component and infer soil and vegetation health. Pellant et al. (2000) suggest using biological soil crusts as an optional indicator of rangeland health in regions where crusts are present, potentially providing a sensitive measure of departure from ecological health. Using a similar methodology for soil condition assessment, Tongway and Hindley (1995) suggest that cover of crust organisms is a useful indicator of soil stability and nutrient status and cycling in Australian rangelands.

Perhaps the greatest methodological impediment to using biological soil crusts as indicators of rangeland condition for purposes of assessment and monitoring is the lack of knowledge about appropriate reference conditions for crusts, given the spatial heterogeneity of soils and climate throughout their range. Assessment of crust condition requires evaluation of actual cover and composition of biological soil crusts in relation to potential cover and composition. Appropriate soil crust reference conditions would be useful in ecologically based multiple-indicator assessment or monitoring methods such as rangeland health assessment and related techniques (Tongway and Hindley 1995; Pellant et al. 2000; Pyke et al. 2002; Herrick et al. 2005). In many cases, few undisturbed reference areas exist, and we believe the best approach to providing reference conditions is the use of spatial predictive models as a decision support system (Koh and Power 1993). Grand StaircaseEscalante National Monument (GSENM; Colorado Plateau, USA) is a useful study system to attempt a predictive model because it captures much of the heterogeneity in habitat characters seen on the Colorado Plateau in its approximately 800000 ha. Precipitation gradients range from approximately $15-50 \mathrm{~cm}$ annually, and the region is geologically complex, resulting in a large diversity of soils which differ strongly in texture and chemical properties. We set out to formulate a set of models predicting potential crust cover and composition to provide reference conditions for this large, diverse area. We had three specific objectives: 1) to determine the proportion of variance that can be explained in biological soil crust distribution by widely available environmental data in a GIS format; 2) evaluate the accuracy of model predictions; and 3) create GIS data layers that reflect the potential cover of biological soil crusts, and functional groups of crust taxa for the study area. We believe that this information will facilitate the use of crust abundance and compositional data in rangeland assessment and monitoring protocols, thus allowing managers to integrate this indicator of ecosystem condition in their management decisions. Consideration of biological soil crusts in such decisions will tend to conserve biodiversity and key ecosystem processes.

\section{METHODS}

\section{Sampling Scheme}

Predictive modeling efforts should ideally begin with the formulation of a conceptual model based upon literature, preliminary data or observation which guides the sampling design (Guisan and Zimmerman 2000). We used the conceptual model advanced in Bowker et al. (2006) to guide our sampling strategy. Our model hypothesizes that crust composition and cover varies in relation to a hierarchical set of factors, including climate, soil texture, and soil chemistry (Fig. 1). We made an aridity gradient our uppermost sampling stratum by dividing the study area into 3 precipitation brackets $\left(\leq 20 \mathrm{~cm} \cdot \mathrm{y}^{-1}, 20\right.$ $\left.30 \mathrm{~cm} \cdot \mathrm{y}^{-1}, \geq 30 \mathrm{~cm} \cdot \mathrm{y}^{-1}\right)$; these brackets have no particular a priori significance, but each represents about $25 \%-40 \%$ of the study area, and served the purpose of spreading out our sampling along the full precipitation gradient. All sites were classified as 1 of 8 mutually exclusive soil functional types: bentonitic clay soils, calcareous sandy, noncalcareous sandy, gypsiferous soils, siliceous sandy (these are also noncalcareous, but are distinguished by large grain size, and siliceous cementing in parent materials), non-bentonitic fine soils, Kaiparowits (a sandy-textured parent material that is unique because it forms highly erodible badlands)-derived soils, and limestonederived soils. Soils were assigned to these functional soil types using information in the GSENM Soil Survey (US Department of Agriculture-Natural Resource Conservation Service [USDANRCS] 2005), and were verified by cross-referencing with the extensive field observations of crust distribution as a function of soil characters of an expert consultant (Kent Sutcliffe, USDA-NRCS Soil Scientist). 
Calcium carbonate content of soils affects nutrient mobility (Lajtha and Schlesinger 1988), and has been observed in past work to be correlated with soil crust cover and composition (Ponzetti and McCune 2001; Bowker et al. 2006). Due to greater pore space, sandy soils can be easier for cyanobacterial filaments to penetrate, whereas somewhat finer soils can provide an inherent stability and enhanced water retention that might favor slower-growing mosses and lichens (USDA-NRCS 1999). Soils containing smectitic clays such as bentonite expand and contract upon wetting and drying, respectively (USDANRCS 1999), and result in an unstable surface for colonization. Our past work has demonstrated the importance of these factors to crust abundance and composition (Bowker et al. 2005). Gypsiferous soils are known to support a distinct crust flora (Rajvanshi et al. 1998).

\section{Survey Methods}

All possible combinations (some did not exist in GSENM) of functional soil type $\times$ precipitation bracket were sampled and replicated for a total of 114 sites. Only sites with relatively minor disturbance impacts were acceptable for sampling because such sites are most likely to display the potential biological soil crust cover and composition. Randomized sampling was impossible because acceptable sites were rare, and access was exceedingly difficult due to remoteness of sites. Instead, all acceptable sites that were located were sampled. Although the great majority of GSENM is at least mildly impacted by past livestock activity, it was possible to sample low disturbance sites in areas that are fully or partially inaccessible to livestock or that are distant from sufficient water or quality forage. Land-use history was deduced using a combination of interviews with GSENM range and science staff, distance from water and herbaceous forage, presence/density of hoof prints, livestock dung or grazed plants, and relative prevalence of unpalatable plant species that tend to increase in relative abundance under longterm influence of livestock grazing. In an attempt to quantify grazing disturbance history, this information was used to create an ordinal ranking of grazing disturbance (ranging from 1-10) to test whether we were able to reduce the effect of disturbance in our data. The following categories were used: 1) probably never grazed by domestic livestock; 2) historic grazing with $50+$ year rest; 3) light historic grazing with 25-49 year rest; 4) heavy historic grazing with 25-49 year rest, or light historic grazing with 1024 year rest; 5) heavy historic grazing with 10-24 year rest; 6) active allotment that is $>1$ mile from water, is geographically isolated, and has poor forage; 7) active allotment with 2 of the 3 above conditions satisfied; 8) active allotment with 1 of 3 of the above conditions satisfied; 9) active allotment with none of the above conditions satisfied, but little evidence or record of recent grazing in the area; and 10) same as 9 on site, but evidence of moderate to heavy grazing nearby. Where possible, sites with a slope of $\leq 5^{\circ}$ were sampled to reduce variance caused by slopeaspect effects; only 8 sites with slope of $>5^{\circ}$ were sampled, with the most extreme slope being $13^{\circ}$.

To measure crust cover and composition, we used a step point-intercept transect (modified from Evans and Love 1957) consisting of 300 points (spaced about $2 \mathrm{~m}$ apart). Instead of a pin, a vertically placed knife was used. Where possible this was broken down into 2 parallel transects at least $20 \mathrm{~m}$ apart.

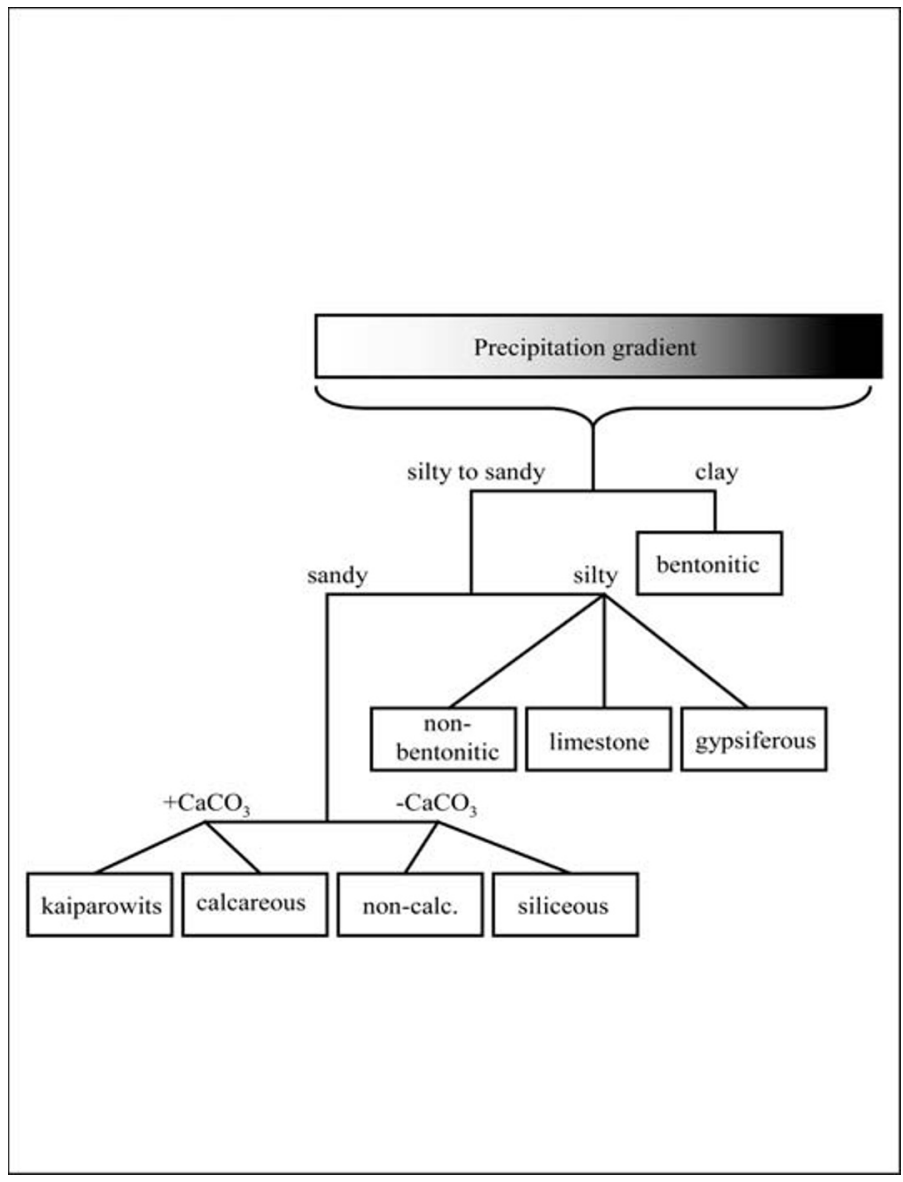

Figure 1. Diagrammatic representation of the sampling scheme used in this study.

Observations were noted for 4 crust types (moss, lichen, light, or dark cyanobacterial crust; Table 1), surface rock, light or heavy litter, exposed bedrock, shrub or annual canopies by species, vagrant lichens or cyanobacteria, and shrub or annual stems by species. On approximately every $10 \mathrm{~m}$ the maximal variation in soil microrelief (to the nearest $\mathrm{cm}$ ), within a $5 \mathrm{~cm}^{2}$ quadrat was estimated.

Soils were collected across the surface of the entire site at approximately $20-\mathrm{m}$ intervals, (depth $=0-0.5 \mathrm{~cm}$ ), regardless of whether the point was under a shrub canopy or not or had crust cover or not. To obtain a measurement of average chlorophyll a content in cyanobacterial crusts, an additional set of samples were obtained from interspace soil surfaces nearest to the intervals sampled above that lacked mosses and lichens. Chlorophyll $a$ is a commonly used bioassay for total biomass in cyanobacterial-algal communities (Belnap 1993). At least 20 samples of each type (whole site soil surface, soil surface chlorophyll $a$ sample) were compiled into 2 different composites until approximately $200 \mathrm{~g}$ of soil was obtained for each.

\section{Soil Analysis}

To allow better characterization of functional soil types, the whole site soil surface samples were sent to the Brigham Young University Soil and Plant Analysis Laboratory for analysis for total $\mathrm{N}$ using an automated Dumas method; $\mathrm{NaHCO}_{3}{ }^{-}$ extractable $\mathrm{P}$ and $\mathrm{K}$; $\mathrm{NH}_{4} \mathrm{OAc}$-extractable $\mathrm{K}$; $\mathrm{Ca}, \mathrm{Mg}$, and $\mathrm{Na}$; 
Table 1. Definition and dominant taxa of the 4 crust types quantified in this study.

\begin{tabular}{|c|c|c|}
\hline Soil crust type & Definition & Dominant taxa \\
\hline Light cyanobacterial crusts & $\begin{array}{l}\text { Interception of a cyanobacterial community composed only of motile } \\
\text { filamentous forms, and devoid of surface pigmentation; may or may not } \\
\text { be dense enough to form a cohesive crust }\end{array}$ & Microcoleus vaginatus \\
\hline Dark cyanobacterial crusts & $\begin{array}{l}\text { Interception of a cyanobacterial community composed of both motile } \\
\text { filamentous forms, and surface-bound pigmented forms; always dense } \\
\text { enough to form a cohesive crust }\end{array}$ & Microcoleus vaginatus \\
\hline Moss & Interception of any soil crust moss taxa & $\begin{array}{l}\text { Syntrichia caninervis } \\
\text { Syntrichia ruralis } \\
\text { Anomobryum spp. }\end{array}$ \\
\hline Lichen & Interception of any soil crust lichen taxa & $\begin{array}{l}\text { Collema coccophorum } \\
\text { Collema tenax } \\
\text { Placidium spp. } \\
\text { Psora desipiens }\end{array}$ \\
\hline
\end{tabular}

DTPA-extractable $\mathrm{Fe}, \mathrm{Mn}, \mathrm{Cu}$, and $\mathrm{Zn}$; gypsum by water of hydration; $\mathrm{CaCO}_{3}$ measured as acid neutralizing potential; organic matter by dichromate oxidation; texture by hydrometer; and saturated paste extract $\mathrm{pH}$ and electrical conductivity (Black 1965; Page 1982).

The other set of surface samples (interspace soils lacking mosses and lichens) were analyzed for chlorophyll a concentration using quantitative and qualitative HPLC analysis (Karsten and Garcia-Pichel 1996), modified as described in Bowker et al. (2002). Chlorophyll $a$ was identified by comparative retention times and characteristic absorption spectra, and was quantified as $\mathrm{mg}_{\text {pigment }} \cdot \mathrm{g}_{\text {soil }}{ }^{-1}$ using external standards.

\section{Model Building and Evaluation}

We analyzed our data using classification and regression trees (CART; De'ath and Fabricius 2000) using the program Answer Tree (SPSS 2003). This method dichotomously splits data for a dependent variable based upon the values of predictor variables. At each split the greatest possible amount of variance is explained and subsequent splits can be made resulting in a "tree." The end points of a tree (nodes) represent mutually exclusive combinations of independent variables (e.g., low precipitation gypsiferous soils), and a mean estimate of the dependent variable is generated for each end point. Minimum improvement per split was set at $2 \%$ of the total variance, minimum end node sample size was set at $n=4$, and minimum parent node sample size was set at $n=8$.

We compared multiple methods of statistical model formulation. Two types of models were generated for each predictor variable, "pruned" and "unpruned." Pruning of trees is the removal of nodes to prevent overfitting of data. Overfitted trees can preserve sampling artifacts and anomalies in the data, and tend to perform poorly when evaluated using new data. The trees were automatically pruned using the standard error rule, which states that a node should be pruned if the within node variance is within 1 standard error of that of the full tree. Models were created for the variables lichen cover, moss cover, dark cyanobacterial cover, light cyanobacterial cover, and lichen + moss + dark cyanobacterial crust cover, and chlorophyll $a$ concentration. For the variable chlorophyll $a$, splits were so weak that our protocol would have resulted in zero splits. Therefore, we relaxed our minimum improvement constraint and generated only unpruned models with and without the variable "days since beginning of study." These modifications were allowed to generate hypotheses regarding the poor performance of chlorophyll a models. Models used average annual precipitation (PRISM; Spatial Climate Analysis Service, Oregon State University, Corvallis, OR), elevation (US Geological Survey), and soil functional type (described above) as predictor variables because these data are widely available in a spatial context, or derived from public spatial data. In addition, preliminary models used "days since beginning of study," the "grazing disturbance index" to ensure that these variables were not driving patterns observed.

In predictive distribution modeling, field-collected data are used to statistically formulate a mathematical model (termed training or calibration data), and if possible another field data set is used to evaluate the model (termed evaluation data; Guisan and Zimmerman 2000). Model evaluation was accomplished by splitting the data into training and evaluation datasets. Fourteen data points were randomly sampled without replacement and withheld from the data as an evaluation dataset, and models were built with the remaining data $(n=100)$. Least squares regressions were used to evaluate the coefficient of determination $\left(R^{2}\right)$ between model predictions and the values of the testing data. This procedure was repeated 5 times, resulting in 70 tests of each tree. Regressions were performed using JMP IN 4.0 (SAS 2001). Using the evaluation performance of the various models, the best modeling method was selected for each response variable, and final models were built using the full replication $(n=114)$. The results of the models were mapped in a GIS using ArcMap 9.0 (2003 ESRI).

\section{RESULTS}

\section{Physico-Chemical Differences Among Soil Types}

The soil groupings we used differed considerably in several physico-chemical properties, particularly those which defined the soil groupings, for example, texture, gypsum, and $\mathrm{CaCO}_{3}$ (Table 2). Our soil classification system performed well in summarizing 19 soil characters (Table 3), in that, averaged across soil properties, the within-group coefficient of variation 
Table 2. Ninety-five percent confidence intervals of selected soil properties by soil functional type. ${ }^{1}$

\begin{tabular}{lccccccl}
\hline & $\begin{array}{c}\mathrm{N} \\
(\mathrm{ppm})\end{array}$ & $\begin{array}{c}\mathrm{P} \\
(\mathrm{ppm})\end{array}$ & $\begin{array}{c}\text { Sand } \\
(\%)\end{array}$ & $\begin{array}{c}\text { Clay } \\
(\%)\end{array}$ & $\begin{array}{c}\mathrm{CaCO}_{3} \\
(\%[\mathrm{ANP}])\end{array}$ & $\begin{array}{c}\text { Gypsum } \\
(\%)\end{array}$ & Representative parent material \\
\hline Bentonitic clay soils & $198-369$ & $3.0-6.8$ & $18.3-45.0$ & $35.2-46.7$ & $11.8-18.0$ & $3.1-8.0$ & Tropic shale Fmn. \\
Calcareous sandy soils & $376-536$ & $5.0-7.2$ & $65.0-71.6$ & $14.4-19.2$ & $4.2-7.8$ & $0.6-1.6$ & Kayenta and Entrada Fmns. \\
Gypsiferous soils & $596-1100$ & $3.5-7.5$ & $25.0-37.0$ & $21.7-30.2$ & $11.5-17.8$ & $10.3-28.2$ & Carmel Fmn. Paria River Mbr. \\
Kaiparowits-derived soils & $302-577$ & $2.6-6.8$ & $57.3-70.3$ & $14.6-26.7$ & $20.8-29.7$ & $0.9-3.0$ & Kaiparowits Fmn. \\
Limestone-derived soils & $577-973$ & $10.5-17.8$ & $43.3-56.1$ & $12.2-21.5$ & $8.3-15.1$ & $1.4-3.0$ & Moenkopi Fmn. Timpoweap Mbr. \\
Non-bentonitic fine soils & $252-663$ & $6.8-11.3$ & $39.9-61.4$ & $11.9-21.7$ & $9.2-16.4$ & $0.6-1.8$ & Moenkopi Fmn. Lower Red Mbr. \\
Non-calcareous sandy soils & $479-969$ & $7.4-11.8$ & $64.0-71.8$ & $9.4-16.8$ & $0-3.9$ & $0.4-0.8$ & Straight Cliffs Fmn. Judd Hollow Mbr. \\
Siliceous sandy soils & $119-564$ & $2.6-5.1$ & $78.0-85.7$ & $3.9-12.4$ & $0-3.3$ & $0.1-0.3$ & Navajo Fmn. \\
\hline
\end{tabular}

${ }^{1}$ ANP indicates acid neutralizing potential; Fmn., formation; Mbr., member.

(CV) for these data was 34\% lower than the overall CV. Variance of every soil property considered was reduced by classification into our scheme, especially percent clay, exchangeable $\mathrm{Ca}$, and percent gypsum $(\mathrm{CV}=55 \%, 73 \%$, and $65 \%$, respectively). We were least successful in reducing variance in $\mathrm{Mn}, \mathrm{Cu}$, and total $\mathrm{N}$ (CV reduction $=14 \%, 20 \%$, and $17 \%$, respectively). Limestone-derived and nonbentonitic fine soils were the least variable groups; none of the soil properties exhibited greater within-group coefficient of variation compared to overall CV. In contrast, noncalcareous sandy soils and siliceous soils each had 4 soil properties with greater within-group CV compared to overall coefficient of variation.

\section{Model Evaluation}

Preliminary models predicting percent cover of various soil crust cover types were not driven by the grazing disturbance ranking, so evaluation models were constructed using the main set of predictors only. The variable "days since beginning of study" accounted for the most variance in the chlorophyll $a$ data $\left(\leq 35\right.$ days $=0.0042 \mathrm{mg}_{\text {pigment }} \cdot \mathrm{g}_{\text {soil }}{ }^{-1},>35$ days $\left.=0.0021 \mathrm{mg}_{\text {pigment }} \cdot \mathrm{g}_{\text {soil }}{ }^{-1}\right)$. This result might be related to extreme drought conditions in the second year of the study. An alternative model for chlorophyll $a$ separated sites with bentonitic clay, non-bentonitic fine, and Kaiparowits-derived soils $\left(0.0011 \mathrm{mg}\right.$ pigment $\left.{ }^{\cdot} \mathrm{g}_{\text {soil }}{ }^{-1}\right)$ from all other soil types $\left(0.0027 \mathrm{mg}\right.$ pigment $\left.{ }^{\circ} \mathrm{g}_{\text {soil }}{ }^{-1}\right)$.

Table 3. Coefficient of variation (CV) of 19 soil properties in each soil functional type, mean CV among soil properties in each soil functional type, mean CV among soil functional types for each soil property, and reduction in CV when soils are classified as functional groups $(1-$ [mean within group CV/among group CV]).

\begin{tabular}{|c|c|c|c|c|c|c|c|c|c|c|}
\hline Soil property & $\begin{array}{l}\text { Bentonitic } \\
\text { fine }\end{array}$ & $\begin{array}{l}\text { Calcareous } \\
\text { sandy }\end{array}$ & Gypsiferous & $\begin{array}{c}\text { Kaiparowits- } \\
\text { derived }\end{array}$ & $\begin{array}{l}\text { Limestone- } \\
\text { derived }\end{array}$ & $\begin{array}{l}\text { Non-bentonitic } \\
\text { fine }\end{array}$ & $\begin{array}{l}\text { Non-calcareous } \\
\text { sandy }\end{array}$ & $\begin{array}{l}\text { Siliceous } \\
\text { sandy }\end{array}$ & $\begin{array}{l}\text { Coefficient of } \\
\text { variation }_{\text {among }}\end{array}$ & $\begin{array}{c}\text { Coefficient of } \\
\text { variation reduction }\end{array}$ \\
\hline$P$ & 61.4 & 54.0 & 58.4 & 42.5 & 36.1 & 32.0 & 42.4 & 51.6 & 61.8 & 0.23 \\
\hline K-available & 48.8 & 50.2 & 38.0 & 45.0 & 26.0 & 32.3 & 45.9 & 78.3 & 70.8 & 0.36 \\
\hline Organic matter & 56.6 & 72.8 & 42.9 & 41.4 & 37.4 & 39.2 & 77.7 & 48.2 & 71.2 & 0.27 \\
\hline $\mathrm{pH}$ & 5.8 & 6.0 & 4.0 & 5.3 & 2.9 & 5.4 & 5.0 & 4.1 & 6.0 & 0.20 \\
\hline $\begin{array}{l}\text { Electrical } \\
\text { Conductivity }\end{array}$ & 48.3 & 57.2 & 20.0 & 40.4 & 33.9 & 57.4 & 30.5 & 38.3 & 64.3 & 0.37 \\
\hline Sand & 66.4 & 14.4 & 32.2 & 9.7 & 18.0 & 27.6 & 10.6 & 7.4 & 33.6 & 0.31 \\
\hline Clay & 44.8 & 28.2 & 39.8 & 24.6 & 23.6 & 17.5 & 13.6 & 18.0 & 58.2 & 0.55 \\
\hline Silt & 43.3 & 49.1 & 29.6 & 38.2 & 20.2 & 35.8 & 35.0 & 53.8 & 59.3 & 0.36 \\
\hline $\mathrm{Zn}$ & 54.4 & 62.0 & 43.5 & 43.4 & 53.0 & 38.1 & 84.1 & 103.5 & 79.0 & 0.24 \\
\hline $\mathrm{Fe}$ & 113.6 & 61.0 & 66.9 & 24.7 & 52.3 & 57.1 & 35.2 & 92.8 & 86.3 & 0.27 \\
\hline $\mathrm{Mn}$ & 91.1 & 56.8 & 60.8 & 44.8 & 55.1 & 55.1 & 55.5 & 43.4 & 67.6 & 0.14 \\
\hline $\mathrm{Cu}$ & 35.4 & 32.9 & 47.6 & 33.6 & 32.6 & 36.7 & 31.2 & 34.9 & 44.5 & 0.20 \\
\hline $\mathrm{Ca}$ & 64.1 & 80.2 & 41.8 & 8.2 & 26.8 & 24.5 & 58.1 & 45.6 & 158.8 & 0.73 \\
\hline $\mathrm{Mg}$ & 72.7 & 46.3 & 79.0 & 29.3 & 66.2 & 42.4 & 37.4 & 30.4 & 78.3 & 0.36 \\
\hline K-exchangeable & 42.8 & 40.7 & 31.0 & 16.6 & 32.9 & 33.8 & 37.2 & 34.7 & 63.4 & 0.47 \\
\hline $\mathrm{Na}$ & 67.6 & 85.0 & 23.9 & 126.3 & 10.8 & 96.9 & 112.2 & 55.3 & 102.7 & 0.30 \\
\hline N & 47.2 & 52.5 & 44.9 & 29.8 & 35.6 & 58.4 & 63.6 & 102.5 & 65.5 & 0.17 \\
\hline $\mathrm{CaCO}_{3}$ & 62.0 & 71.0 & 41.8 & 13.8 & 76.6 & 53.8 & 119.2 & 81.4 & 97.5 & 0.33 \\
\hline Gypsum & 68.4 & 138.0 & 62.9 & 49.9 & 50.4 & 62.2 & 58.3 & 101.6 & 208.9 & 0.65 \\
\hline Mean & 57.6 & 55.7 & 42.6 & 35.1 & 36.3 & 42.4 & 50.1 & 54.0 & 77.8 & 0.34 \\
\hline
\end{tabular}


When evaluated, the moss $\left(R^{2}=0.55\right)$, lichen $\left(R^{2}=0.64\right)$, and lichen + moss + dark cyanobacterial $\left(R^{2}=0.64\right)$ models performed very well, the dark cyanobacterial $\left(R^{2}=0.49\right)$ trees performed moderately well, and the light cyanobacterial $\left(R^{2}=0.22\right)$ and chlorophyll $a\left(R^{2}=0.09\right)$ trees performed poorly. The $R^{2}$ values given represent the proportion of variance explained between model predictions and observed values from the testing datasets. With the exception of the light cyanobacterial trees, unpruned trees usually performed better than their pruned counterparts (average improvement in $\left.R^{2}=0.10\right)$. This suggests that the pruning procedure was removing biologically significant nodes, possibly due to small sample size within some nodes.

\section{Final Models}

In the evaluation process, the best model building procedures were identified: unpruned models for lichen, moss, dark cyanobacterial crusts, and lichen + moss + dark cyanobacterial crusts; and a pruned tree for light cyanobacterial crusts. These methods were used to build the final models composed of the full dataset ( $n=114$; Fig. 2 ). Trees were created explaining a large proportion of the variance in the training data. The $R^{2}$ values, measuring the proportion of variance in the training data explained, ranged from 0.69-0.84 (Fig. 2). It is expected that the increased sample size in these final models will yield better predictive value than those used in the evaluation process.

\section{DISCUSSION}

\section{Strengths and Weaknesses of the Models}

Models predicting moss, lichen, and dark cyanobacterial cover separately or summed performed well whereas models predicting light cyanobacterial cover and chlorophyll $a$ concentration performed poorly. Although there is some degree of residual within-node variance, gross errors were very rare during the evaluation process of lichen, moss, and dark cyanobacterial models. In most cases a reasonable estimate of a given cover type was obtained. The 3 used in concert should provide a powerful and flexible means of assessing departure from potential of a site to be evaluated. The utility of the models is enhanced by using GIS. Four GIS data layers are presented in Figure 3. Examination of the map outputs reveals the large degree of variation in potential crust cover across our study area, and that different crust types respond differently to important gradients (Fig. 3).

There are at least 2 limitations to using these data layers as reference conditions in our study area. First, we sampled only relatively flat sites (slope $<5^{\circ}$ ), unless no alternative was available. This was a pragmatic decision that we made for 2 reasons: 1) including the predictors slope and aspect would have required a greater sample size of low-disturbance sites than could be found in and near the study area, and 2) the majority of the most heavily used pastures in the study area exist in relatively flat areas. If a sloping site is to be evaluated, slightly greater overall soil crust cover and relative prevalence of mosses and lichens can be expected on north-sloping sites compared to our data layers, whereas slightly lesser overall crust cover and relative prevalence of cyanobacteria can be expected on southerly-sloping sites (MB personal observation; Nash et al. 1977). This factor is relatively less important than the predictors we did use: annual precipitation, soil type, and elevation (Bowker et al. 2005). The second limitation is that there was a bias toward shallow soils in our sampling, because deeper soils are more productive in terms of livestock forage and consequently more heavily used by livestock. Thus, when a site with deep soils is to be evaluated there is an additional source of uncertainty.

Light cyanobacterial crust models likely performed poorly due to the use of too broad of a definition of this cover type. For the purposes of this study, light crusts ranged from any colonization of cyanobacteria lacking dark sunscreen pigments (visible in the field under a handlens) whether or not a cohesive crust was formed, to very thick cohesive crusts that lacked surface colonization of darkly pigmented cyanobacteria. Thus, in some extreme cases where sparse colonization was common but cohesive crusts were rare, the data indicated high cover of light cyanobacterial crusts when actual biomass was very low. A possible alternative that could solve this problem would be to use an ordinal system of classifying cyanobacterial crust development in future efforts. This could be accomplished using observations on the cohesiveness and darkness (a surrogate for the colonization of dark pigmented cyanobacteria) of crusts.

The low predictive power of the chlorophyll $a$ model might be due to the effects of an extreme drought. The southwestern United States experienced an unprecedented drought event in 2002 , resulting in widespread woody plant mortality (Breshears et al. 2005) and decreased cyanobacterial cell counts, but no visible impact on crust cover (M.B., unpublished data, 2002). At any given time and place chlorophyll $a$ can be a useful relative measure of total cyanobacterial-algal biomass. However, chlorophyll $a$ and direct cyanobacterial cell counts can vary independently of one another due to environmental conditions (encountered in Bowker et al. 2002). The best predictor of chlorophyll $a$ was the variable, "days since beginning of study." It is possible that as the study (and drought) progressed, the photosynthetic crust components experienced photodegradation of chlorophyll $a$ and/or mortal-

Figure 2. Final CART tree models for: a) total moss cover; b) total lichen cover; c) total dark cyanobacterial cover; d) total light cyanobacterial cover; and e) moss + lichen + dark cyanobacterial cover. Trees are followed in a dichotomous fashion downward. Predictor variables used appear above the split, and values to either side indicate the values of the data on that side of the split. The vertical length of each branch is proportional to the variance explained by that split. At each end point, mean percent cover estimates appear in italic type, with standard deviations in parentheses. The $R^{2}$ value represents the amount of variance explained in the data that is used to build the model; it does not reflect the evaluation performance (summarized in text). L indicates limestone; NB, nonbentonitic fine soil; NC, noncalcareous sandy; S, siliceous sandy; C, calcareous sandy; G, gypsiferous; B, bentonitic clay; K, kaiparowits (see text for descriptions). 


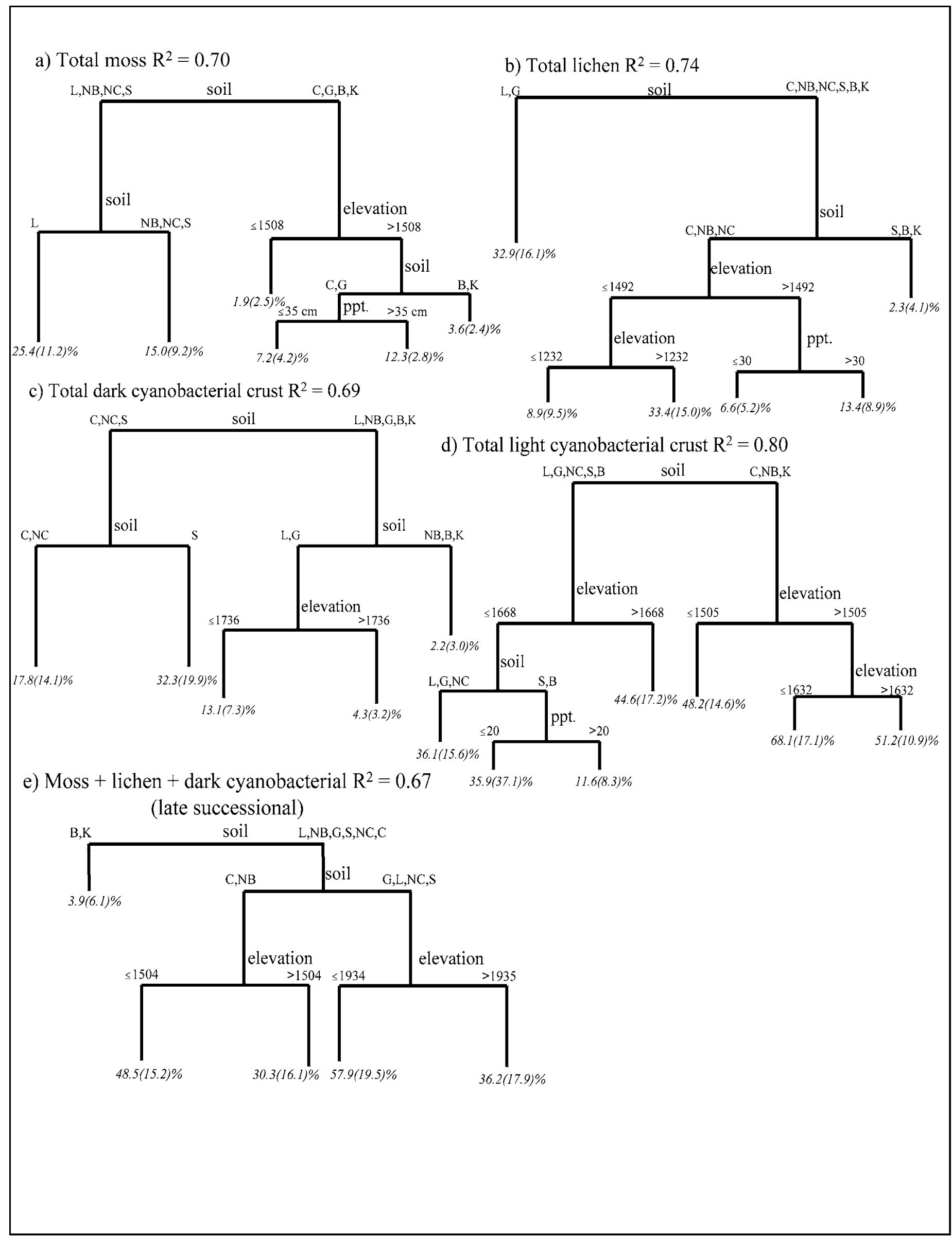



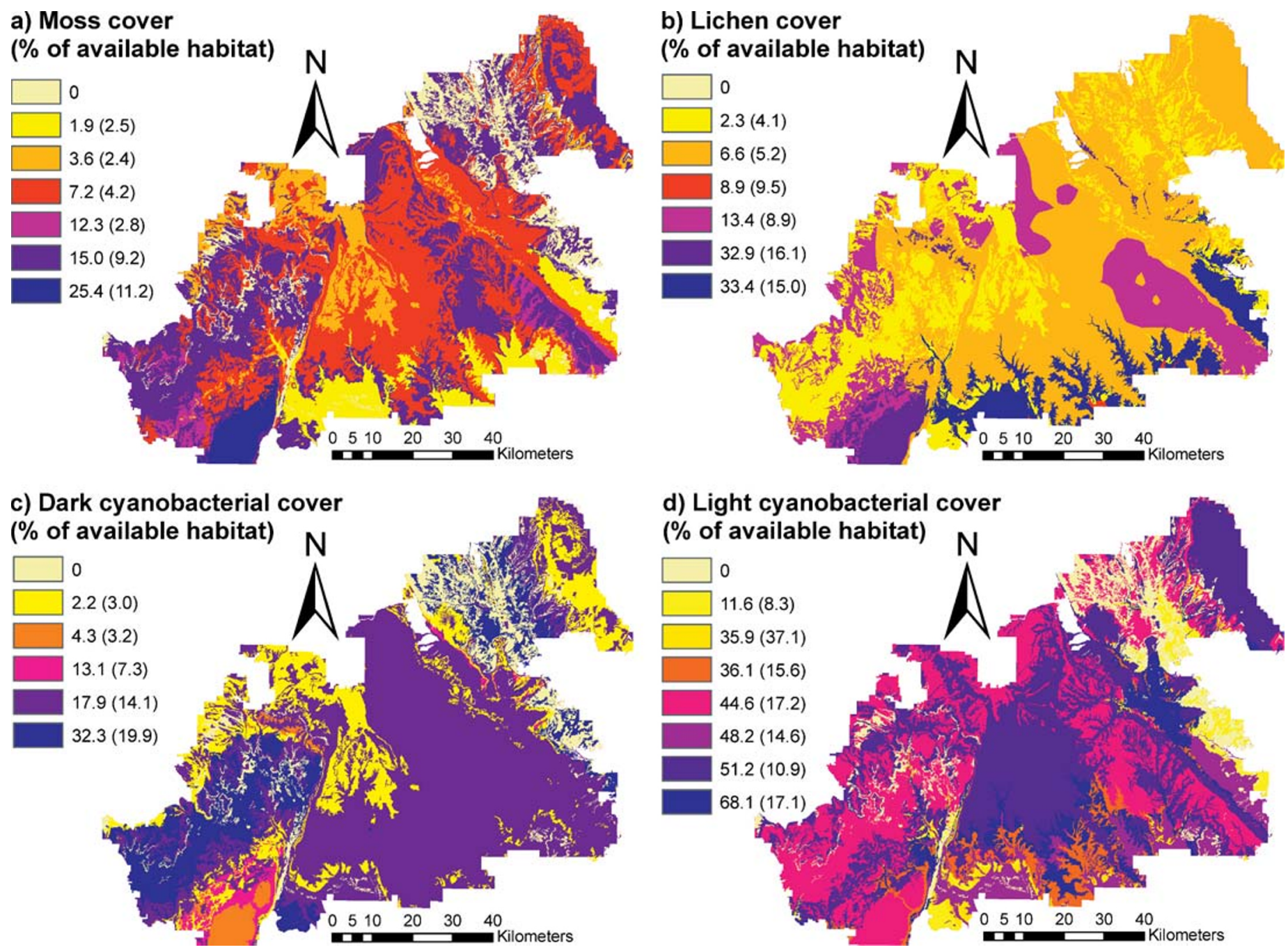

Figure 3. Four example GIS data layers of models generated in this study of: a) moss cover; b) lichen cover; c) dark cyanobacterial cover; and d) light cyanobacterial cover. Mean cover is presented as percent of available habitat, with standard deviation in parentheses.

ity. It was possible to create a model of low predictive power if "days since beginning of study" was ignored. This model separates bentonitic clay, non-bentonitic fine, and Kaiparowits-derived soils (lower chlorophyll $a$ ) from other soil types (higher chlorophyll $a$ ).

Perhaps the greatest overall strength of this modeling approach is its generality. The Colorado Plateau is a complex mosaic of starkly differing soils, but using the soil classification scheme advanced in these models allows a reasonable simplification of this variability. A logical extension of this work would be to increase the extent of the models to the entire Colorado Plateau ecoregion, an area of $326390 \mathrm{~km}^{2}$ (Ricketts et al. 1999). A more extensive set of models would allow inclusion of basalt-derived soils (not present in GSENM) and better characterization of limestone-derived soils (relatively rare in GSENM), both of which are common in the Southern Colorado Plateau. It would also allow better representation of important gradients such as aridity, elevation, and latitude, and potentially important gradients such as the ratio of cool season to warm season precipitation (Jeffries and Klopatek 1987; Eldridge 1996; Rosentreter and Belnap 2003).The advantage of an expanded model is that it would be useful to all agencies managing grazing and other soil-disturbing land uses on the Colorado Plateau (National Park Service, Bureau of Land Management, US Forest Service, etc.).

Similar techniques could be applied to other regions as well. Many workers have noted the dichotomy between lichen crust communities on calcareous and noncalcareous soils (e.g., Ponzetti and McCune 2001; Turk and Gartner 2003); thus this distinction might represent a fundamental first step in classification of soil-landscape types. Eldridge (1996) advanced a landscape classification scheme of 7 types in southeast Australia defined by soil characters (including calcareousness), plant communities, physiography and hydrology. Rosentreter and Pellant (unpublished data, 1994) use a matrix of plant community composition and structure, soil surface texture, and disturbance history to describe landscape types and semiquantitatively predict potential biological soil crust abundance. The USDA-NRCS ecological site scheme (USDA-NRCS 2005) combines soil texture, climate, and dominant vegetation to estimate potential range productivity. We believe that because it addresses factors important to biological soil crusts, the USDA- 
NRCS ecological site scheme might have some predictive power for the potential cover and composition of soil crusts; however, because whole-profile (as opposed to surface) characters are emphasized and important chemical gradients are not accounted for, the scheme is not optimized for this purpose. While no single soil-landscape classification scheme is likely to be useful everywhere, these examples demonstrate the possibility of predictively modeling potential biological soil crust cover in many regions of the world.

\section{Incorporating Biological Soil Crusts into Range Management}

Desertification of semiarid and arid rangelands is widespread and costly, impacting $85 \%$ of North America's and $73 \%$ of the world's drylands (Dregne and Chou 1992). The most widespread contributor/accelerator of rangeland desertification is livestock grazing, and 1 of its main symptoms is accelerated soil erosion (Neff et al. 2005). Rangeland use will always be partially driven by socioeconomic factors, but there is a history of balance with resource conservation-driven range management. Range management and ecology in the United States share common origins and were closely allied until the 1940s (Pendeleton 1989). Traditional range management methods rested upon a Clementsian belief in a monoclimax vegetation state (Clements 1936), with the implication that the climax state also offers the best forage for livestock (Pendelton 1989). Similarity indices quantitatively compared current conditions to a Clementsian climax (Dyksterhuis 1949) and later to a desired vegetation state (Moir 1989). A large departure from the desired conditions might have resulted in a change in management strategy, such as lowered stocking rates.

Despite early recognition of the need to assess the rate of soil erosion on grazing land (Ellison 1949), no method was widely accepted in the United States and the cattle forage emphasis in rangeland assessment continued until recently. Rosentreter and Eldridge (2002) have argued that crust lichens should be monitored in an effort to quantify the ecological condition of an area and its degree and direction of change. Because "ecological condition" is not a readily measured property, surrogate measures of indicator variables must be made instead. The authors maintain that soil lichens are 1 such useful indicator of good ecological condition, because they contribute nutrients and reduce soil loss, among other important functions. Similarly, Klopatek (1992) suggests that, because of their sensitivity to disturbance, crust cover and cyanobacterial-algal biomass (chlorophyll $a$ ) have potential for being indicators of disturbance or lack of disturbance. There are a few examples of the use of soil crust abundance as an indicator of ecological condition of ecosystems. Ecologically based (rather than economically based) assessments of site and soil condition, including measurement of crust cover, were developed in arid and semiarid Australian rangelands (Tongway and Smith 1989; Tongway and Hindley 1995) and later applied in Iran (Ata Rezaei et al. 2006) and Spain (Maestre and Cortina 2004). A quantitative index describing the dust trapping, soil stabilizing, and hydrological functions of biological soil crusts was proposed by Rosentreter and Eldridge (2002) and is still undergoing testing.

Rangeland health assessment and associated monitoring techniques (Pellant et al. 2000; Pyke et al. 2002; Herrick et al. 2005) are recently developed, ecologically based methods that integrate numerous indicators of 3 key ecological attributes: soil/site stability (ability of a site to restrict loss of soil resources), hydrologic function (capacity of a site to capture, store, and release water, and the resistance/resilience of this property), and integrity of the biotic community (capacity of a site to support characteristic community structure and function, and the resistance/resilience of this property). The end result of this approach is a qualitative (Pellant et al. 2000) or quantitative (Herrick et al. 2005) measurement of departure from the appropriate reference conditions for the 3 key attributes. Pellant et al. (2000) suggest that crusts are 1 potential indicator that would be useful in dryland range ecosystems. Biological soil crusts relate strongly to all 3 of the key attributes in most of the arid and semiarid rangelands of the world, and should be among the most important of the indicators for all 3 on the Colorado Plateau. The rangeland health assessment method suggests describing the degree of departure from potential crust cover using an ordinal scale, although a quantitative assessment based upon the data in this study is also quite possible. The models presented in this paper provide estimates of potential crust conditions in a user-friendly map format (Fig. 3) so that this important indicator can be used in the rangeland health or other range assessment/monitoring protocol.

\section{MANAGEMENT IMPLICATIONS}

We propose that a primary objective of rangeland management should be to slow desertification by preventing rangelands from crossing degradation threshholds (Aronson et al. 1993; Archer and Stokes 2000) beyond which positive feedbacks continue the desertification process and natural succession cannot return a site to its previous state. Economically based decisions regarding establishment of stocking rates should be considered only after this goal has been met.

In our research we have provided an estimate of what biological soil crusts would look like across our study area, in the absence of disturbance (Fig. 3). This information is a reference point to compare to the current status of biological soil crusts in rangelands, and use the degree of departure between actual and potential biological soil crust cover as 1 of several indicators of degradation in an ecologically based range assessment protocol. The degree of departure from the undisturbed state that is possible before a degradation threshold is crossed is seldom known a priori. This piece of information should become the subject of intensive research in range management so that ecologically based assessment methods (using biological soil crusts as 1 indicator) can be used to detect when a site might be in danger of crossing a degradation threshold.

\section{ACKNOWLEDGMENTS}

We thank Dr Kent Sutcliffe for providing valuable consultation concerning the planning of this research. Dr Thom O'Dell, Sean Stewart, Harry Barber, Paul Chapman, and other members of the GSENM staff assisted with site suggestions or other logistical support. Drs John Spence and Tim Graham provided helicopter access to remote sites. Laura Pfenninger, Sarah Bartlett, Jennifer Brundage, Kate Kurtz, Cecil Nelms, 
Elaine Kneller, Walt Fertig, and Laura Fertig provided indispensable field assistance. We thank Drs John Prather and Walt Fertig for statistical modeling input. Drs Roger Rosentreter and Lloyd Stark provided consultation on difficult lichen and moss identifications.

\section{LITERATURE CITED}

Alexander, R. W., and A. Calvo. 1990. The influence of lichens on slope processes in some Spanish badlands. In: J. B. Thornes [ED.]. Vegetation and erosion. New York, NY: John Wiley and Sons. p. 385-398.

Archer, S., and C. Stokes. 2000. Stress, disturbance and change in rangeland ecosystems. In: 0. Arnalds and S. Archer [EDS.]. Rangeland desertification. Dordrecht, the Netherlands: Kluwer Academic Publishers. p. 17-38.

Aronson, J., C. Floret, E. Le Floch, and C. Ovalle. 1993. Restoration and rehabilitation of degraded ecosystems in arid and semiarid regions I. A view from the south. Restoration Ecology 1:8-17.

Ata Rezael, S., H. Arzani, and D. Tongway. 2006. Assessing rangeland capability in Iran using landscape function indices based on soil surface attributes. Journal of Arid Environments 65:460-473.

BELNAP, J. 1993. Recovery rates of cryptobiotic crusts: inoculant use and assessment methods. Great Basin Naturalist 53:89-95.

BeLnAP, J. 1995. Surface disturbances: their role in accelerating desertification. Environmental Monitoring and Assessment 37:39-57.

BELNAP, J. 1996. Soil surface disturbances in cold deserts: effects on nitrogenase activity in cyanobacterial-lichen soil crusts. Biology and Fertility of Soils 23:362-367.

BeLnAP, J., AND D. J. EldRIDGE. 2003. Disturbance and recovery of biological soil crusts. In: J. Belnap and 0. L. Lange [EDS.]. Biological soil crusts: structure, function, and management. Berlin, Germany: Springer-Verlag. $p$. 363-384.

Belnap, J., R. Prasse, and K. T. Harper. 2003. Influence of biological soil crusts on soil environments and vascular plants. In: J. Belnap and O. L. Lange [EDS.] Biological soil crusts: structure, function, and management. Berlin, Germany: Springer-Verlag. p. 281-302.

Beymer, R. J., AND J. M. KLopatek. 1991. Potential contribution of carbon by microphytic crusts in pinyon-juniper woodlands. Arid Soil Research and Rehabilitation 5:187-198.

Black, C. A. 1965. Methods of soil analysis. Part 2. Madison, WI: American Society of Agronomy, Inc. 1572 p.

Bowker, M. A., J. Belnap, D. W. Davidson, and H. Goldstein. 2006. Correlates of biological soil crusts across a continuum of spatial scales: support for a hierarchical conceptual model. Journal of Applied Ecology 43:152-163.

Bowker, M. A., J. Belnap, D. W. Davidson, and S. L. Phillips. 2005. Evidence for micronutrient limitation of biological soil crusts: importance to arid-lands restoration. Ecological Applications 15:1941-1951.

Bowker, M. A., S. C. Reed, J. Belnap, And S. L. Phillips. 2002. Temporal variation in community composition, pigmentation, and $F_{v} / F_{m}$ of desert cyanobacterial crusts. Microbial Ecology 43:13-25.

Breshears, D. D., N. S. Cobb, P. M. Rich, K. P. Price, C. D. Allen, R. G. Balice, W. H. Romme, J. H. Kastens, M. L. Floyd, J. Belnap, J. J. Anderson, O. B. Myers, and C. W. MEYER. 2005. Regional vegetation die-off in response to global-change-type drought. Proceedings of the National Academy of Science 102:15144-15148.

Clements, F. E. 1936. Nature and structure of the climax. Journal of Ecology 24:252-284.

Danin, A., and E. Gaynor. 1991. Trapping of airborne dust by mosses in the Negev Desert, Israel. Earth Surface Process Landforms 16:153-162.

DE'ATH, G., AND K. E. FabRicIUs. 2000. Classification and regression trees: a powerful yet simple technique for ecological data analysis. Ecology 81:3178-3192.

Dregne, H. E., AND N.-T. Chou. 1992. Global desertification dimension and costs. In: H. E. Dregne [ED.]. Degradation and restoration of arid lands. Lubbock, TX: Texas Tech University Press. p. 249-281.

Dyksterhuis, E. J. 1949. Condition and management of rangeland based on quantitative ecology. Journal of Range Management 2:104-115.

ELDRIDGE, D. J. 1996. Distribution and floristics of terricolous lichens in soil crusts in arid and semi-arid New South Wales, Australia. Australian Journal of Botany 44:581-599.

ELLISON, L. 1949. The ecological basis for judging condition and trend on mountain rangeland. Journal of Forestry 47:786-795.

Evans, R. A., And R. M. Love. 1957. The step-point method of sampling: a practical tool in range research. Journal of Range Management 10:208-212.

Evans, R. D., AND J. R. EhleRinger. 1993. A break in the nitrogen cycle of arid lands? Evidence from $\delta \mathrm{N}^{15}$ of soils. Oecologia, 99:233-242.

Guisan, A., and N. E. Zimmerman. 2000. Predictive habitat models in ecology. Ecological Modeling 135:147-186.

Harper, K. T., and J. R. Marble. 1988. A role for non-vascular plants in management or arid and semiarid rangelands. In: P.T. Tueller [ED.]. Vegetation science applications for rangeland analysis and management. Dordrect, Netherlands: Kluwer Academic Publishers. p. 136-169.

Herrick, J. E., J. W. Van Zee, K. M. Havstaad, L. M. Burkett, and W. G. Whitford. 2005. Monitoring manual for grassland, shrubland, and savannah ecosystems. Volume II: design, supplementary methods and interpretation. Las Cruces, New Mexico: USDA-ARS Jornada Experimental Range. 206 p.

JefFRiES, D. L., AND J. M. KLoPATEK. 1987. Effects of grazing on the vegetation of the blackbrush association. Journal of Range Management 40:390.

Jones, C. G., J. H. LaWton, And M. Shachak. 1997. Positive and negative effects of organisms as physical ecosystem engineers. Ecology 78:1946-1957.

Karsten, U., and F. Garcia-Pichel. 1996. Carotenoids and mycosporine-like amino acid compound in members of the genus Microcoleus (cyanobacteria): a chemosystematic study. Sytematic Applied Microbiology 19:119-126.

KLOPATEK, J. M. 1992. Cryptogamic crusts as potential indicators of disturbance in semi-arid landscapes. In: J. H. McKenzie, D. E. Hyatt, and V. J. McDonald [EDs.]. Ecological indicators. Vol 1. London, UK: Elsevier Applied Science. p. 773-786.

KoH, D. K., AND J. M. Power. 1993. Considerations for integrating spatial information in decision support systems. In: J. W. Stuth. and B. G. Lyons [EDS.]. Decision support systems for the management of grazing lands. New York, NY: Parthenon Publishing Group. p.141-158.

LAJTHA, K., AND W. H. SChlesinger. 1988. The biogeochemistry of phosphorus cycling and phosphorus availability along a desert soil chronosequence. Ecology 69:24-39.

Maestre, F. T., and J. Cortina. 2004. Insights into ecosystem composition and function in a sequence of degraded semiarid steppes. Restoration Ecology 12:494-502.

Mazor, G., G. J. Kidron, A. Vanshak, and A. Abeliovich. 1996. The role of cyanobacterial exopolysaccharides in structuring desert microbial crusts. FEMS Microbiology Ecology 21:121-130.

MoIR, W. H. 1989. History of development of site and condition criteria for range condition within the U.S. Forest Services. In: W. K. Lauenroth and W. A. Laycock [EDS.]. Secondary succession and the evaluation of rangeland condition. Boulder, CO: Westview Press. p. 49-76.

Nash, T. H., S. L. White, and J. E. Marsh. 1977. Lichen and moss distribution and biomass in hot desert ecosystems. The Bryologist 80:470-479.

Neff, J. C., R. L. Reynolds, J. Belnap, and P. Lamothe. 2005. Multi-decadal impacts of grazing on soil physical and biogeochemical properties in southeast Utah. Ecological Applications 15:87-95.

PAGE, A. L. 1982. Methods of soil analysis. Part 2. Madison, WI: American Society of Agronomy, Inc. 1142 p.

Pellant, M., P. Shaver, D. A. Pyke, and J. E. Herrick. 2000. Interpreting indicators of rangeland health. Bureau of Land Management Technical Reference 1734-6. $130 \mathrm{p}$.

Pendelton, D. T. 1989. Range condition as used in the Soil Conservation Service. In: W. K. Lauenroth and W. A. Laycock [EDS.]. Secondary succession and the evaluation of rangeland condition. Boulder, CO: Westview Press. p. 17-34.

Ponzetti, J. M., and B. P. McCune. 2001. Biotic soil crusts of Oregon's shrub steppe: community composition in relation to soil chemistry, climate, and livestock activity. Bryologist 104:212-225.

Pyke, D. A., J. W. Herrick, P. Shaver, and M. Pellant. 2002. Rangeland health attributes and indicators for qualitative assessment. Journal of Range Management 55:584-597.

Rajvanshi, V., L. L. St. Clair, B. L. WebB, and C. C. Newberry. 1998. The terricolous 
lichen flora of the San Rafael Swell, Emery County, UT, USA. In: M. G. Glenn, R. C. Harris, R. Dirig, and M. S. Dole. [EDs.]. Lichenographia Thomsoniana: North American Lichenology in honor of John W. Thomson. Ithaca, NY: Mycotaxon. p. 399-406.

Reynolds, R. L., J. Belnap, M. Reheis, P. Lamonthe, and F. Luiszer. 2001. Aeolian dust in Colorado Plateau soils: nutrient inputs and recent change in source. Proceedings of the National Academy of Sciences 98:7123-7127.

Ricketts, T. H., E. Dinerstein, D. M. Olsen, C. J. Loucks, W. Eichbaum, D. DellaSala, K. Kavanagh, P. Hedao, P. T. Hurley, K. M. Carney, R. Abell, and S. Walters. 1999. Terrestrial ecoregions of North America: a conservation assessment. Washington DC: Island Press. $486 \mathrm{p}$.

Rosentreter, R., and J. Belnap. 2003. Biological soil crusts of North America. In: J. Belnap and O. L. Lange [EDS.]. Biological soil crusts: structure, function, and management. Berlin, Germany: Springer-Verlag. p. 31-50.

Rosentreter, R., and D. J. EldRidge. 2002. Monitoring biodiversity and ecosystem function: grasslands, deserts and steppe. In: P. L. Nimis, C. Scheidegger and P. A. Wolseley [EDS.]. Monitoring with lichens-monitoring lichens. Boston, MA: Kluwer Academic Publishers. p. 223-237.
SAS. 2001. JMP IN 4.0. SAS Institute, Inc. Cary, NC.

SPSS. 2003. Answer Tree 3.0. SPSS Inc., Chicago, IL.

Tongway, D. J., AND N. Hindley. 1995. Manual for assessment of soil condition of tropical grasslands. Canberra, Australia: CSIRO. 60 p.

Tongway, D. J., AND E. L. Smith. 1989. Soil surface features as indicators of rangeland site productivity. Australian Rangeland Journal 11:15-20.

TuRK, R., AND G. Gartner. 2003 Biological soil crusts of the subalpine, alpine, and nival areas in the Alps. In: J. Belnap and O. L. Lange [EDS.]. Biological soil crusts: structure, function, and management. Berlin, Germany: SpringerVerlag. p. 67-74.

USDA-NRCS. 1999. Soil taxonomy: a basic system of soil classification for making and interpreting soil surveys. Washington DC: US Department of Agriculture. $871 \mathrm{p}$.

USDA-NRCS. 2005. Grand Staircase-Escalante National Monument soil survey. Washington DC: US Department of Agriculture. $580 \mathrm{p}$.

WarRen, S. D. 2001. Biological soil crusts and hydrology in North American deserts. In: J. Belnap and 0. L. Lange [EDS.]. Biological soil crusts: structure, function, and management. Berlin, Germany: Springer-Verlag. p. 327-337. 